\title{
Gedagtes oor die arbeidsregtelike posisie van predikante, pastore en priesters as werknemers van die kerk
}

Author:

Fanie van Jaarsveld

Affiliation:

${ }^{1}$ Department of Mercantile Law, Faculty of Law, University of Pretoria, Pretoria, South Africa

\section{Note:}

Prof. Van Jaarsveld is Emeritus professor and research associate in the Department of Mercantile Law, in the Faculty of Law at University of Pretoria, Pretoria, South Africa.

Correspondence to: Fanie van Jaarsveld

Email:

fanievanjaarsveld@gmail.

com

Postal address: Private Bag X20, Hatfield 0028, Pretoria, South Africa

\section{Dates:}

Received: 20 Mar. 2015

Accepted: 24 May 2015

Published: 06 Nov. 2015

How to cite this article: Van Jaarsveld F., 2015, 'Gedagtes oor die arbeidsregtelike posisie van predikante, pastore en priesters as werknemers van die kerk', HTS Teologiese Studies/Theological Studies 71(3), Art. \#2946, 6 pages. http://dx.doi.org/10.4102/ hts.v71i3.2946

\section{Copyright:}

(c) 2015. The Authors.

Licensee: AOSIS

OpenJournals. This work is licensed under the Creative Commons Attribution License.

\section{Read online:}

Scan this QR code with your smart phone or mobile device to read online.
Thoughts on the labor law position of pastors and priests as employees of the church. The issue of labour-law relationships between pastors or priests and their employers (churches) is controversial because they (pastors or priests) are often regarded as employees and often not. These issues are discussed on the basis of problems in the South-African positive law and English law. In discussing the question about the nature of this labour-law relationship, a twostage approach is suggested, especially when bearing in mind that the employment contract forms the basis of the labour-law relationship between the two parties.

\section{Inleiding}

Die vraagstuk of predikante, pastore en priesters as werknemers onderworpe is aan arbeidswetgewing (soos die Wet op Arbeidsverhoudinge, 66 van 1995') is sedert 1999 in groot omstredenheid gehul, aangesien hulle dikwels nie as werknemers of as 'gewone' werknemers beskou is nie, maar in 'n wasige kleed van gedienstigheid en godsdienstigheid ten aansien van sleutelfeite en -regsaspekte gehul is. Veel besinning en bespreking het alreeds oor die netelige aangeleentheid plaasgevind, en onlangs het so 'n geleentheid hom nogeens in die positiewe reg voorgedoen. ${ }^{2}$ Dieselfde vraagstuk was veral sedert 1984 'n knellende probleem op die Engelse arbeidsregtelike terrein. ${ }^{3}$

Ten einde die problematiek van die regsverhouding tussen predikante en hulle Kerke (werkgewers) te verstaan, is dit nodig om die bespreking toe te lig met enkele gevallestudies wat in die praktyk voorgekom het. Die onderhawige probleem sal daarna in die Suid-Afrikaanse reg aan die hand van die positiewe reg bespreek word, waarna vervolgens 'n regsvergelykende bespreking van die regsposisie in Engeland onderneem sal word voordat daar ' $n$ evaluering van die aard en regsimplikasies van die regsverhouding tussen predikante, priesters en pastore en hulle werkgewers sal geskied en ten slotte sal enkele slotbeskouings ter oorweging voorgelê word.

\section{Suid-Afrikaanse positiewe reg}

Die volgende problematiese gevalle het in hoofsaak sedert 1999 in die howe ter sprake gekom:

Schreuder $v$ Nederduitse Gereformeerde Kerk, Wilgespruit ${ }^{4}$ : Ds. Noel Schreuder (Applikant) is vanaf 'n plattelandse gemeente, waar hy die enigste predikant was, na 'n stadgemeente in Roodepoort beroep, te wete die NG Kerk, Wilgespruit (die Eerste Respondent), waar hy een van vyf predikante was. Hy is uit diens ontslaan deur die Respondent-gemeente nadat hy skuldig bevind is aan klagtes van onbekwaamheid (onbevoegdheid). Schreuder is ook daarvan beskuldig dat hy onenigheid in die geledere van die gemeente se predikante veroorsaak het. In die Hof het die Respondent 'n beswaar in limine geopper dat die Hof nie oor die jurisdiksie beskik om die arbeidsdispuut aan te hoor nie, aangesien Schreuder nie as 'n werknemer van die gemeente (sy werkgewer) ingevolge die Wet op Arbeidsverhoudinge, 66 van 1995, gekwalifiseer het nie. Die Hof het egter die beswaar verwerp om redes wat later bespreek sal word. ${ }^{5}$ Die Hof het voorts ook bevind dat daar nie meriete in die beweerde klagtes teen Schreuder was nie en gelas dat hy in diens herstel moet word. Die saak het 'n uitmergelende 74 hofdae geduur!

1. Hierna aangedui as WAV.

2.Sien Universal Church of the Kingdom of God v CCMA (2014) 35 ILJ 1678 (AH) en Afd B5 infra.

3.Sien Afd. C infra.

4.(1999) 20 ILJ 1936 (AH)

5.Sien Afdeling D2 infra. Sien ook Petrus v Evangelical Lutheran Church (ongerapporteerde saak No JR 804/10 van 29 Junie 2012) (AH) en verwys na in (2014) 35 ILJ 1678 (AH) op 1687 
The Church of the Province of South Africa Diocese of Cape Town $v$ CCMA $^{6}$ : Die St. George Anglikaanse Kerk in Kaapstad, die Applikant (C), het 'n leraar van hom, ene priester Mathebula (M), van twee klagtes van wangedrag aangekla. $\mathrm{M}$ is deur ' $\mathrm{n}$ kerktribunaal aan die klagtes skuldig bevind, sy kerklisensie is ingetrek, maar hy is nie ontslaan nie. Die priester is egter verbied om enige amp in die Kerk te beklee of enige ampsdiens van die kerk vir' $n$ periode van vyf jaar te behartig. Sy ordening ('ordination') is ook nie herroep nie, maar hy sou nie op enige finansiële voorregte geregtig wees nie. $\mathrm{M}$ het die dispuut na $\mathrm{KVBA}^{7}$ ('CCMA') verwys, waar $C$ 'n beswaar in limine geopper het dat die priester nie 'n werknemer was soos deur WAV vereis word nie. ${ }^{8}$ Die Kerk het ook aangevoer dat, indien KVBA egter wel oor jurisdiksie beskik het, dit die Kerk se konstitusionele reg op vryheid van godsdiens en assosiasie oorskry het. KVBA het albei die besware verwerp, waarop $C$ die beslissing op hersiening na die Arbeidshof geneem het.

Die Arbeidshof het egter bevind dat daar geen bedoeling by nóg Mathebula (priester), nóg die Kerk was om 'n regsgeldige afdwingbare dienskontrak te sluit nie, met ander woorde daar het geen kontraktuele verhouding behalwe 'n spirituele verhouding, tussen die party bestaan nie. ${ }^{9}$

Salvation Army (South African Territory) $v$ Minister of Labour $^{10}$ : Die Applikant (SA), 'n wêreldwye organisasie, het by die Arbeidshof vir 'n verklarende bevel aansoek gedoen dat sy beamptes, wat hy as predikers georden en aangestel het, nie as werknemers vir doeleindes van ' $n$ aantal arbeidswette (o.a. WAV, Wet op Basiese Diensvoorwaardes, 75 van 1997 en die Wet op Billike Werksgeleenthede, 55 van 1998) beskou moet word nie.

SA het aangevoer dat dit nie sy ampsdraers as werknemers behandel nie en dat daar slegs 'n spirituele verhouding tussen SA en sy ampsdraers bestaan wat beheer word deur'n religieuse gewete en 'n verbond met God. Die ampsdraers het ook nie hulle dienste aan SA verkoop nie, ook nie 'n salaris of toelaag ontvang nie, alhoewel hulle slegs 'n lewenstoelaag ('living allowance') ontvang het. Daar word ook geen kontrole oor die uitvoering van hulle spirituele take uitgeoefen nie. Die Arbeidshof het bevind dat, in die lig van al die

\section{6.(2001) 22 ILT2274 (AH).}

7.Kommissie vir Versoening, Bemiddeling en Arbitrasie.

8.Sien art. 213 van WAV, saamgelees met art. 185 van WAV.

9.Sien bl. 2289 C-G. Sien egter ook Paxton v The Church of the Province of South Africa Diocese of Port Elizabeth (ongerapporteerde saak No NH 11/2/1985) (PE) verwys na in (2001) 22 ILJ 2274 (LC) op 2289 C-F), waar die Nywerheidhof hom in geen onduidelike taal nie uitgelaat het oor die verhouding tussen dieselfde Kerk (maar' $n$ ander gemeente) en die betrokke priester: 'The picture which emerges both from a study of the relevant provisions of the constitution and canons, the acts, and, the actual features of the relationship between the parties, is not one of employment. Rather, it is a picture of a spiritual relationship, commencing in formal terms with the applicant taking an oath of canonical obedience to the bishop, being invested with the spiritual office of a priest, being licenced to officiate as a priest and authorized to administer the sacraments and perform various other administrations and duties to administer the sacraments and perform various other administrations and duties in accordance with the canons of the church. Certainly the applicant was subject to the authority and discipline of the respondent, but such authority and discipline are derived not from any employment relationship between the parties, but from office-bearers in positions of ecclesiastical superiority in relation to the applicant."

10.(2005) 26 ILJ 126 (AH). omstandighede van die saak, SA nooit dienskontrakte met sy ampsdraers gesluit het nie. Daar was ook geen sodanige bedoeling by nóg SA nóg sy ampsdraers nie. Derhalwe is die ampsdraers nie werknemers ingevolge die relevante arbeidswetgewing nie. ${ }^{11}$

Wagenaar v Uniting Reformed Church in $S A^{12}$ : Ds. Wagenaar (W) was 'n predikant van die Pretoria-gemeente van die Respondent-kerk. Sedert 1994 was daar onvrede en verdeeldheid in die betrokke gemeente. Die probleem het nie tussen $\mathrm{W}$ en die gemeente en die kerkraad as sodanig bestaan nie, maar slegs tussen hom en enkele individuele lede. Dit het gedurende 2001 gekulmineer in 'n skrywe van $\mathrm{W}$ aan die kerkraad waarin hy hulle versoek het dat die band tussen hom en die gemeente losgemaak word (en nie die Respondent-kerk nie). Laasgenoemde het inderdaad later wel die band losgemaak.

Die dispuut is deur W na KVBA verwys, waar aangevoer is dat hy onbillik uit die diens van die Respondent ontslaan is. Laasgenoemde het egter ontken dat W'n werknemer van die Respondent was of dat hy hoegenaamd ontslaan is. KVBA het egter bevind dat $\mathrm{W}$ wel 'n werknemer ingevolge die bepalings van WAV is, dat hy inderdaad ontslaan is, maar dat dit substantief sowel as prosesueel billik geskied het. ${ }^{13}$

Universal Church of the Kingdom of God $v$ Commission for Conciliation Mediation $\mathcal{E}$ Arbitration ${ }^{14}$ : In hierdie resente 2014-saak het die vraagstuk weer opnuut opgeduik of geestelikes soos predikante, pastore en priesters, as werknemers van hulle Kerke beskou moet word wat in 'n arbeidsregtelike verhouding teenoor laasgenoemde staan, en of daar bloot ' $n$ geestelik-religieuse verhouding tussen die betrokke partye bestaan.

Die feite in casu was effe problematies deurdat die pastoor in gedrang, Myeni (M), in 1998 as kwekeling-pastoor by die Kerk (UC) begin het. Hy het egter in 2010'n dokument getiteld 'Declaration of voluntary service' geteken, nadat hy alreeds gedurende 2004 as 'n pastoor georden is. Die 'Declaration' het egter slegs sy posisie as kwekeling-pastoor ('trainee pastor') gereël. M is volgens hom gedurende 2011 onbillik ontslaan deur UC en het die dispuut na KVBA verwys. UC het by wyse van 'n punt in limine aangevoer dat $\mathrm{M}$ nie 'n werknemer was nie. Die arbiter het egter bevind dat $\mathrm{M}$ wel 'n werknemer was en dat hy onbillik ontslaan is. UC het beide die bevindings op hersiening na die Arbeidshof geneem, welke hof beslis het dat bevinding dat $\mathrm{M}$ wel 'n werknemer was, korrek was. ${ }^{15}$

\section{Die regsposisie in die Engelse Reg}

Die Engelse howe het aanvanklik die standpunt gehuldig dat die priesters en pastore nie werknemers van die kerk was 11. Bil. 131-132.

12.[2005] 1 BALR 127 (KVBA).

13.BII. 133-137.

14.(2014) 35 ILJ 1678 (AH).

15.Die redes vir die bevinding sal later in Afdeling D infra bespreek word (vervolg). 
nie, ${ }^{16}$ maar bloot ampsdraers, ${ }_{17}^{17}$ aangesien 'the spiritual nature of the job is inconsistent with a contract of employment'. Verder is aangevoer dat, aangesien die rol en funksies van priesters en pastore, ongeag die kerkgenootskap, noodwendig so 'n mate van onafhanklike oordeel en diskresie geverg het dat sy/haar verhouding met die kerk of die kerklike gesagsowerhede, nie 'n dienskontrak kon behels het nie. ${ }^{18}$

Daar was ook 'n tempering (verslapping) in hierdie benadering toe in Diocese of Southwark $v$ Coker $^{19}$ beslis is dat daar geen reël bestaan wat die dienskontraktuele status verbied nie, maar dat daar inderdaad wel 'n sterk vermoede teen sodanige status gelding geniet. In die Industriële Tribunaal is bevind dat Coker as pastoor inderdaad 'n werknemer was, maar later op appèl, het die Engelse 'Court of Appeal' beslis dat Coker geensins 'n kontrak met die kerk gesluit het nie. Die Hof het gesteun op 'n dictum van die Parfit-saak ${ }^{20}$ waar die volgende verklaar is:

... I have no hesitation in concluding that the relationship between a church and a minister is not apt, in the absence of clear indications of a contrary intention in the document, to be regulated by a contract of service. ${ }^{21}$

Die Hof het ook verklaar dat die eenvoudige rede vir die afwesigheid van 'n kontrak tussen die kerk en die godsdienstige priesters die feit was dat die bedoeling om kontraktuele verhouding tussen hulle te sluit, ontbreek het. ${ }^{22}$ Die Hof vat die regsposisie dan as volg saam:

(1) Not every agreement constitutes a binding contract. Offer, acceptance and consideration must be accompanied by an intention to create a contractual relationship giving rise to legally enforceable obligations.

(2) The intention is to be objectively ascertained. In the case of an ordinary commercial transaction it will be for the person who contends that there was no contrast to establish that the intention to create a binding contract has been negative.

(3) In some cases, however, there is no contract, unless it is positively established by the person contending for the contract that there was such an intention to create a binding contractual relationship. This is such a case $\ldots^{23}$

Weerspieëlend van die breë gevoel destyds het L.J. Straughton ook die volgende insiggewende uitlating gemaak: ${ }^{24}$

One can say that a minister of religion serves God and serves his congregation, but does not serve an employer. That seems to me

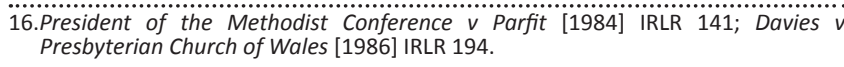

to be accurate in general terms ... I agree with ... [the] conclusion that in general the duties of a minister of religion are inconsistent with an intention to create contractual relations. There may be some subsidiary contract as to a pension, or the occupation of a house; but there is not a contract that he will serve a terrestrial employer in the performance of his duties ...

'n Paar jaar vroeër het die House of Lords ook gewys op 'n moontlike dualisme by die bepaling van die regsaard tussen kerk en priester toe as volg in Davies v Presbyterian Church of Wales $^{25}$ verklaar is:

My Lords, it is possible for a man to be employed as a servant or as an independent contractor to carry out duties which are exclusively spiritual. But in the present case the pastor of a Church cannot point to any contract between himself and the Church ... The duties owed by the pastor to the Church are not contractual or enforceable. A pastor is called and accepts the call. He does not devote his working life but his whole life to the Church and his religion. His duties are defined not by the contract but by conscience.$^{26}$

Die posisie in die Engelse reg het egter verander en kentering het ingetree in Stewart $v$ New Testament Church of $\mathrm{God}^{27}$ toe die diensstatus ('employment status') van 'n predikant ingevolge Engelse arbeidswetgewing ${ }^{28}$ pertinent ter sprake gekom het. Die 'Court of Appeal' het 'n bevinding van die 'Employment Appeal Tribunal' bevestig dat die Tribunaal geregtig was om te bevind dat 'n predikant van die Respondent-kerk inderdaad 'n 'werknemer' vir doeleindes van 'n onbillike ontslag was. Een kommentator het die situasie as volg opgesom:

... that the indirect result of Percy ${ }^{29}$ was to leave the matter to tribunals as a question of fact. The spiritual nature of the work may be a factor against an employment relationship ... but in some cases ... that may be outweighed by other factors consistent with employment. ${ }^{30}$

Onlangs het die siening dat arbeidswetgewing groter gelding in die geledere van kerkamptenare (predikante, priesters, ens.) behoort te geniet, effense stremming ervaar toe die 'Supreme Court' in President of the Methodist Conference $v$ Preston $^{31}$ beslis het dat me. Preston, 'n senior predikant in die Metodistekerk, nie 'n werknemer was nie, maar 'n dienende predikant 'pursuant to the lifelong relationship into which she had entered when she was ordained'. ${ }^{32}$ Die Hof wys daarop dat

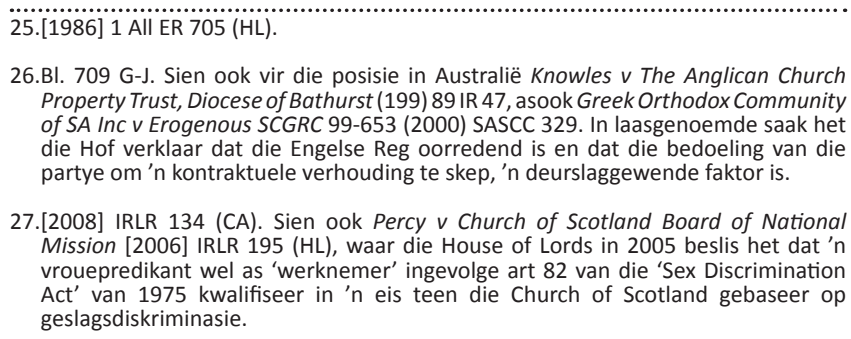

26.BI. 709 G-J. Sien ook vir die posisie in Australië Knowles v The Anglican Church Property Trust, Diocese of Bathurst (199) 89IR 47, asook Greek Orthodox Community of SA Inc v Erogenous SCGRC 99-653 (2000) SASCC 329. In laasgenoemde saak het die Hof verklaar dat die Engelse Reg oorredend is en dat die bedoeling van die die Hof verklaar dat die Engelse Reg oorredend is en dat die bedoeling van
partye om 'n kontraktuele verhouding te skep, 'n deurslaggewende faktor is.

27.[2008] IRLR 134 (CA). Sien ook Percy v Church of Scotland Board of National Mission [2006] IRLR 195 (HL), waar die House of Lords in 2005 beslis het dat ' $n$ vrouepredikant wel as 'werknemer' ingevolge art 82 van die 'Sex Discrimination Act' van 1975 kwalifiseer in ' $n$ eis teen die Church of Scotland gebaseer op geslagsdiskriminasie.

28.Sien ook art. 230 van die Employment Rights Act 1996.

29.Sien vtnt 27.

30.Brennan ao supra par 115

31.[2013] UKSC 29 (SC).

32.Ibid. 
die uitgangspunte van die howe in die verlede problematies was:

Part of the vice of the earlier authorities was that many of them proceeded by way of abstract categorisation of ministers of religion generally. The correct approach is to examine the rules and practices of the particular church and any special arrangements made with the particular minister.. $.33^{33}$

But, as with all exercises in contractual construction, these documents and any admissible evidence on the parties' intentions fall to be construed against the factual background. ${ }^{34}$

In 'n minderheidsuitspraak, is lady Hale meer uitgesproke oor die bestaan van 'n dienskontrak. Sy wys daarop dat daar niks intrinsieks ('intrinsic') in die predikantstatus is wat onbestaanbaar is met die gelding van 'n kontrak tussen kerk en predikant nie. So kom dit algemeen voor dat rabbi's deur spesifieke sinagoges in diens geneem word. Verder word priesters teenswoordig ook deur die Church of England ingevolge voorwaardes aangestel wat uitdruklik bepaal dat hulle klagtes rakende onbillike ontslag by 'n 'Employment Tribunal' aanhangig kan maak..$^{35}$

\section{Evaluering en slotbeskouings van regsposisie Verskillende benaderingswyses}

Op die oog af het die vraagstuk waarmee die Hof in die onlangse Universal Church-saak ${ }^{36}$ gekonfronteer is, ten spyte van die effe problematiese 'Declaration of voluntary service', wat pastoor Myeni geteken het, ${ }^{37}$ nie te gekompliseerd voorgekom nie. Die Hof het die vraagstuk as volg omskrywe: 'Is a pastor who signed a document that he is in the voluntarily service of a church an employee or not?'38

Die probleem in casu was egter dat die 'Declaration' net op kwekelingpastore betrekking gehad het, terwyl Myeni dit slegs gedurende 2010 geteken het, ten spyte van die feit dat hy reeds ses jaar vantevore, gedurende 2004, tot volle pastoor georden is. Die Kerk het egter aangevoer dat pastoor Myeni nie 'n werknemer was nie, maar die arbiter het Myeni gesteun in sy siening dat hy wel een was. ${ }^{39}$

Hierteenoor, in die vroeëre ander belangwekkende saak, het die Hof in die Church of the Province-gewysde ${ }^{40}$ die onderhawige vraagstuk vanuit 'n ander hoek as volg geformuleer: '.. in a church and clergy relationship, the

33.Par 26.
35.Par 10.
36.Par $36-37$.
37.Ibid.
38.BI. $1680 \mathrm{D.}$
39.BI. $1600 \mathrm{E.}$
40.Supra (vtnt 6).

crucial question is whether, at the time the parties concluded the offer and acceptance, they intended to create a legally binding contractual relationship ${ }^{41}$... $^{42}$

Die Kerk het getuig dat 'n priester nie as 'n dienaar van die Kerk beskou word nie; terwyl die Kerk die raamwerk vir 'n priester se werk verskaf deur sy konstitusie en ander kerklike voorskrifte:

... the priest is regarded as working for God, ... The [Church] simply ... provided the sphere within which priests serve God arising out of their calling ... It is for that reason $\quad \ldots$ hat priests are said to be called of God and serving God and offering their lives to God - his precludes the Anglican Church ... from speaking of employing priests. ${ }^{43}$

Die priester, Myeni, het egter getuig dat die lisensie wat hom toegelaat het om as ampsdraer te mag optree, inderdaad 'n dienskontrak gekonstitueer het, aangesien dit die kulminering van vele onderhandelinge was wat die uitreiking van die lisensie voorafgegaan het. Dit, tesame met die onderhandelinge, die korrespondensie wat 'n werksaanbod bevat het, asook 'n uiteensetting van die voordele verbonde aan die pos, die feitelike posisie dat hy verplig was om bepaalde verpligtinge uit te voer in ruil vir spesifieke voordele en dat hy verantwoording aan 'n meerdere ('superior') verskuldig was, alles daarop gedui het dat sy posisie teenoor die Kerk een van werknemer en werkgewer was. ${ }^{44}$

Die arbiter het in KVBA bevind, ${ }^{45}$ soos reeds aangedui, dat Myeni as priester, wel 'n werknemer ingevolge WAV was, inagnemend die gemeenregtelike posisie, die statutêre definisie van werknemer asook die 'dominante-indruktoets' soos neergelê in Smit v Workmen's Compensation Commissioner. ${ }^{46}$ Die Hersieningshof het egter bevind dat die arbiter versuim het om vas te stel of daar enige geldige en bindende kontrak tussen die Kerk en Myeni bestaan het en dat dit 'n wesenlike aspek was. Oënskynlik het die arbiter aanvaar dat daar wel 'n kontrak bestaan het. Hy het die aard van die ooreenkoms, met inagneming van die verpligtinge van die partye, bepaal sonder om vas te stel of die partye 'n afdwingbare dienskontrak gesluit het. ${ }^{47}$

Die Hof wys daarop dat ' $n$ belangrike aspek die vraagstuk is of ' $n$ dienskontrak ' $n$ voorvereiste vir die daarstelling van ' $n$ diensverhouding is. Die Hof stem nie saam met die interpretasie van die definisie van ' $n$ werknemer, soos vervat in $\mathrm{WAV}^{48}$ dat 'n dienskontrak inderdaad afdwingbaar is, 
selfs al was dit nie die bedoeling van die partye nie. ${ }^{49}$ Die Hof verklaar dan:

It is patently easier to gather whether or not there is an employer and employee relationship by reference to the duties and obligations, but to do so would be to go against the very basic principle that governs our law of contract, and that is that the parties must have intended to enter into a legally enforceable contract, because the enforceability of duties and obligations is dependent upon it..$^{50}$

Die Hof het eventueel bevind dat, aangesien 'n dienskontrak 'n conditio sine qua non vir die daarstelling van 'n diensverhouding is en daar in casu geen afdwingbare dienskontrak tussen die Kerk en Myeni, die priester, bestaan het nie, die partye nie werknemer en werkgewer, soos voorsien in WAV, kan wees nie. ${ }^{51}$

In die Universal Church-saak ${ }^{52}$ is die voorgaande beslissing egter daarvan onderskei. Die Hof het verklaar dat in gedagte gehou moet word dat die vermoedens ten gunste van werknemerskap, soos vervat in art. 200A van WAV (gedurende 2002 in werking gestel), nog nie ten tye van die uitspraak van die Church of the Province-gewysde gegeld het nie. ${ }^{53}$ Die Hof wys daarop dat nie alleen art. 200A nie, maar ook die 'Code of good practice: Who is an employee ${ }^{54}$ in ag geneem moet word by die bepaling of die pastoor 'n werknemer was. ${ }^{55}$ Die Hof bevind ook dat daar 'n verhouding tussen Kerk en die pastoor bestaan het: 'The pastor rendered services quite literally, in the form of devotional services - in the name of the church'. ${ }^{56}$ Die Hof wys daarop dat ook minstens ses van die faktore vervat in art. 200A aanwesig is in die verhouding en dat beide die Church of the Province- ${ }^{57}$ en Salvation Armybeslissings ${ }^{58}$ nie die voordeel van die leiding ('guidance') wat die 'Code of good practise' verskaf, gehad het nie.59

Die Hof maak ook pertinent melding van 'n omstrede bepaling, vervat in art. 200A, wat bepaal dat die vermoede geld ongeag die vorm van die kontrak. $^{60}$ Die bepaling is omstrede, want dit kan tog nie korrek wees om ten gunste van die vermoede van ' $n$ dienskontrak te bevind indien dit op onbetwiste getuienis van die partye blyk 'n lasgewingskontrak te wees nie. Slegs indien die vorm van die kontrak onseker is en betwis word, behoort dié bepaling te geld. Die Hof bevind dan dat die Kerk nie daarin geslaag het

\section{BI. $2286 \mathrm{G} 22871 \mathrm{D}$.}

50.BI. $2287 \mathrm{H}-\mathrm{I}$

51.BI. $2289 \mathrm{H}-\mathrm{I}$.

52.Supra (vtnt 14).

53.BI. 1682E-F.

54.Sien Gazette 29445 Gen N 1774 gepubliseer 1 Desember 2006.

55.BI. 1683D-F en sien ook arts 203(3) en 203(4) van WAV.

56.BI. $1683 \mathrm{H}$.

57.Supra (vtnt 6).

58.Supra (vtnt 10).

59.BI. 1683H-1684B

60.BI. $1684 \mathrm{H}$. om die vermoede dat die betrokke pastor wel 'n werknemer was, te weerlê nie. ${ }^{61}$

Alhoewel dit nie duidelik so gestel word nie, is die grondslag van die Hof se benadering in die Universal Church-saak ${ }^{62}$ klaarblyklik gefundeer op fasette van die uitspraak ${ }^{63}$ in die beslissing van 'Kylie' $v$ Commission for Conciliation, Mediation $\mathcal{E}$ Arbitration $^{64}$ waar beslis is dat die beskerming wat art. 23(1) van die Grondwet aan 'n werknemer verleen, ook geld in geval laasgenoemde se dienskontrak met sy werkgewer ongeldig was, en daar dus nie meer 'n regtens afdwingbare kontrak bestaan nie. ${ }^{65}$ Dit sou egter hoogs omstrede en na my mening ook onsuiwer wees om op grond hiervan die afleiding te maak dat ' $n$ werkgewer en 'n werknemer sonder 'n kontraktuele diensverhouding, regte en verpligtinge teenoor mekaar kan afdwing. So 'n afleiding (of benadering) sou substantiewe dele van o.a. die volgende artikels van die Wet op Arbeidsverhoudinge van 1995 kragteloos maak, nl. artikels 23, 25, 26, 65, 186(1), 186(2), 190, 197, 197A, 198B, 199, 200A, asook groot dele van die Wet op Basiese Voorwaardes, 75 van 1997, ens. Die betekenis van die 'Kylie'-saak ${ }^{66}$ is egter belangrik, naamlik dat howe oor 'n diskresie beskik om in die geval van ongeldige dienskontrakte, met behulp van die toepassing van art. 23(1) van die Grondwet, die streng toepassing van die par delictum-reël te verslap indien openbare belang oorwegings of 'simple justice between man and man' dit regverdig. ${ }^{67}$

\section{Versoenbaarheid van verskillende benaderingswyses}

Die vraag wat ten slotte beantwoord moet word, is of die bogemelde twee benaderingswyses soos dit in die Church of the Province- ${ }^{68}$ en Universal Church-uitsprake ${ }^{69}$ uitdrukking vind, met mekaar versoenbaar is, veral ook in die lig van die minder omstrede maar bekende beslissing van Schreuder $v$ Nederduitse Gereformeerde Kerk, Wilgespruit. ${ }^{70}$

Dit blyk dat die vertrekpunt in die resente Universal Churchuitspraak meer op 'n ad personam-basis geskoei is - wie is die persoon wat die dienste gelewer het, wat is die arbeidsregtelike

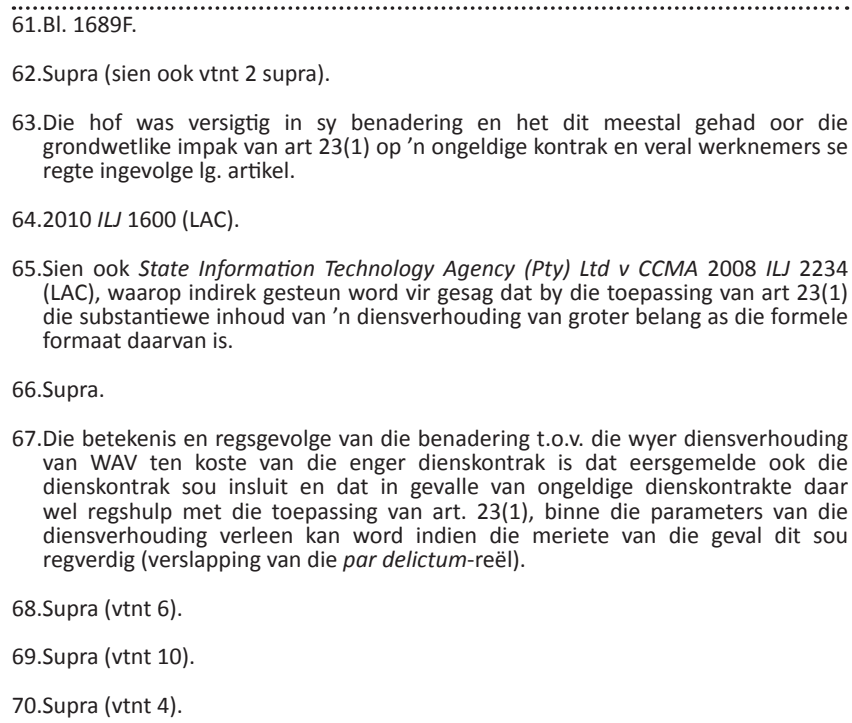

65.Sien ook State Information Technology Agency (Pty) Ltd v CCMA 2008 ILJ 2234 (LAC), waarop indirek gesteun word vir gesag dat by die toepassing van art 23(1) die substantiewe inhoud van ' $n$ diensverhouding van groter belang as die formele formaat daarvan is.

66.Supra.

67. Die betekenis en regsgevolge van die benadering t.o.v. die wyer diensverhouding van WAV ten koste van die enger dienskontrak is dat eersgemelde ook die dienskontrak sou insluit en dat in gevalle van ongeldige dienskontrakte daar wel regshulp met die toepassing van art. 23(1), binne die parameters van die diensverhouding verleen kan word indien die meriete van die geval dit sou regverdig (verslapping van die par delictum-reël).

68.Supra (vtnt 6).

69.Supra (vtnt 10).

70.Supra (vtnt 4). 
aanduiding van art. 200A se vermoedens en wat bepaal die Goeie-praktyk-kode in dié verband - in die lig van die toepaslike feite van die saak - terwyl dit in die Church of the Province meer op 'n ad rem-grondslag gefundeer is: bestaan daar 'n geldige bindende kontrak op grond van aanbod en aanname (uitdruklik of stilswyend) tussen die twee partye waaruit so 'n bedoeling blyk. Die Hof vervolg dan:

The undisputed evidence led by the applicant's witness was that there never was an intention on the part of the applicant to create a legally binding employment contract. The third respondent's submission that his intention was indeed so was contradicted by his very evidence that the relationship as a licencee with the applicant was governed by ecclesiastical law.

In the circumstances, while it is so that the duties and obligations of one to the other could be interpreted as constituting an employment contract, the duties and obligations, like the offer, acceptance and consideration cannot create an employment contract where the parties themselves had not intended one to come into existence. ${ }^{71}$

Na my mening is die twee gewysdes nietemin met mekaar versoenbaar as die volgende in gedagte gehou word: Die vertrekpunt by elke ondersoek van hierdie aard behoort te wees of daar hoegenaamd 'n kontraktuele verhouding tussen die partye bestaan en nie of die faktore vervat in die art. 200A-vermoede aanwesig is, en of die riglyne van die 2006 Goeie-praktyk-kode enige oplossing bied nie. In Catlin $v$ $C C M A^{72}$ word die benadering as volg ondersteun:

In SA Broadcasting Corporation v McKenzie (1999) 20 ILJ 585 (LAC) the court set out important characteristics of the contract of employment and contract of work. Some of these characteristics have been incorporated in section 200A of the LRA. Incorporation of these considerations in section 200A does not do away with the principle that the relationship of the parties must be gathered from the contract. It is therefore necessary to look at the provisions of the contract before applying the presumptions set out in section 200A. ${ }^{73}$

By die hantering en beantwoording van die vraagstuk rakende die aard van die regsverhouding behoort daar 'n twee-stadium-benadering gevolg te word. Artikel 200A en die riglyne vervat in die Goeie-praktyk-kode van 2006 moenie as 71.BI. $2288 \mathrm{~F}-\mathrm{H}$.

72.[2004] 8 BLLR $748(\mathrm{AH})$.

73.BI. 751B-C. Dit was duidelik ook die gedagtegang in die Church of the Province beslissing supra op bl 2288E-F, bl $2289 \mathrm{H}-\mathrm{I}$. die alfa en omega by die beantwoording van vrae rakende die regstatus van predikante en priesters beskou word nie, maar moet slegs in die tweede stadium aanwending vind na die bestaan al dan nie van ' $n$ kontraktuele verhouding tussen die partye in die eerste stadium afgehandel is. Indien daar wel so 'n verhouding bestaan, maar die regsaard daarvan onseker is, behoort art. 200A en die Kode van Goeie Praktyk toegepas te word. Dié werkwyse is in die Schreuder-gewysde ${ }^{74}$ gevolg, maar reeds gedurende die eerste stadium is tot 'n oplossing vir die probleem gekom toe dit uit die getuienis geblyk het dat die 'beroepsbrief' van die predikant 'n dienskontraktuele regsverhouding tussen die partye geskep het.

Die benadering is na my mening prakties en suiwer as in gedagte gehou word dat die dienskontrak die grondslag vir die verhouding tussen die Kerk en predikante en priesters lê en soos ook verklaar is:

The contract of employment links the employer and the employee in an employment relationship - irrespective of the form that employment relationship takes. The existence of an employment relationship is the starting point for the application of all labour law rules ...75

Indien bostaande werkwyse gevolg word, sal die waarheid en praktiese sin van die volgende stelling wat deur lady Hale in die beslissing van President of the Methodist Conference $v$ Preston $^{76}$ gemaak het, ook duidelik blyk:

... everything in this relationship looks like an employment relationship. If it looks like a duck, walks like a duck and quacks like a duck, it probably is one. ${ }^{77}$

\section{Erkenning Mededingende belange}

Die outeur verklaar dat hy geen finansiële of persoonlike verbintenis het met enige party wat hom nadelig of voordelig kon beïnvloed het in die skryf van hierdie artikel nie.

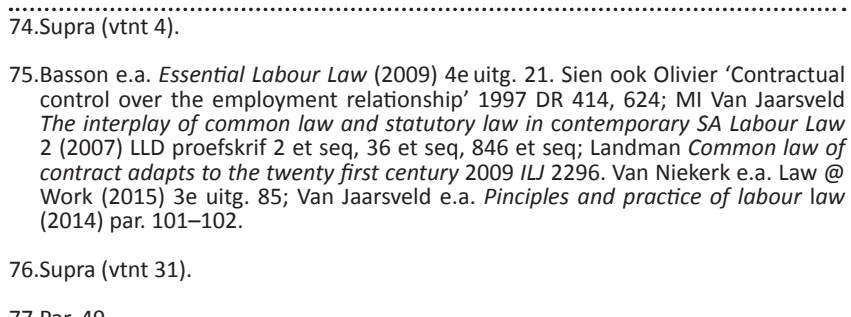
77.Par. 49. 